\title{
HLA-DMB wt Allele
}

National Cancer Institute

\section{Source}

National Cancer Institute. HLA-DMB wt Allele. NCI Thesaurus. Code C150055.

Human HLA-DMB wild-type allele is located in the vicinity of 6p21.32 and is approximately $6 \mathrm{~kb}$ in length. This allele, which encodes HLA class II histocompatibility antigen, DM beta chain protein, plays a role in facilitating the presentation of antigenic peptides. 